\title{
HUBUNGAN TINGKAT PENGETAHUAN DAN SIKAP IBU BALITA DENGAN KEJADIAN DIARE DI PUSKESMAS BUSUNGBIU II KABUPATEN BULELENG
}

\author{
Luh Santini ${ }^{1}$, I Made Bulda Mahayana ${ }^{2}$
}

\begin{abstract}
Diarrheal disease is still a health problem in Indonesia, in general the morbidity and mortality rate in toddlers is quite high and often causes extraordinary events. This study aims to determine the relationship of knowledge and attitudes of mothers of children under five with the occurrence of diarrhea in Puskesmas Busungbiu II Buleleng Regency. This type of research is observational analytic with a cross sectional approach and statistical tests using chi-square analysis test. The number of respondents was 40 people and the determination of the sample using purposive sampling techniques. The results showed that respondents who had a good level of knowledge with toddlers who did not have diarrhea were 24 (85.7\%). Whereas respondents 23 (92\%) had positive attitudes with toddlers without diarrhea. Statistical test results using the chi square test on the knowledge and attitude variables towards diarrhea variables, $p=0,000<\alpha(0.05)$ which means that Ho is rejected. Conclusion means that there is a significant or significant relationship between the level of knowledge and attitudes of mothers of children under five with the incidence of diarrhea. It is recommended for health workers to be more active and creative in providing health education regarding the handling of diarrheal diseases.
\end{abstract}

Keywords: Knowledge, Attitude and Diarrhea

\section{PENDAHULUAN}

Penyakit diare hingga saat ini masih menjadi masalah kesehatan, secara umum angka kesakitan dan kematian pada balita yang dilaporkan oleh seorang petugas kesehatan dan kader kesehatan mengalami peningkatan dan sering menimbulkan kejadian luar biasa. Diare merupakan pengerluaran tinja yang lebih dari tiga kali sehari dan pada neonates lebih dari empat kali sehari dengan atau tanpa lender darah, secara tidak normal yang ditandai dengan peningkatan volume dan ke-enceran tinja (1).
Berdasarkan data register Managemen Terpadu Balita Sakit pada Puskesmas Busungbiu II Tahun 2016 menunjukkan bahwa balita yang menderita diare memiliki ibu berpendidikan SD sebanyak $17 \%$, SMP sebanyak $11 \%$, SMA sebanyak $67 \%$ dan PT sebanyak $10 \%$. Sikap ibu dari hasil wawancara dengan ibu balita, sebagian besar disebabkan dari pola makanan dengan kebiasaan mengkomsumsi makan ringan dan susu siap saji. Kematian balita karena diare merupakan salah satu situasi yang 
rentan, kehidupan balita ini dipandang rentan karena seorang balita memiliki ketergantungan yang tinggi pada orang tuanya terutama ibu, apabila ibu lalai menjalankan tanggung jawabnya dalam penanganan diare balita maka balita akan menghadapi masalah terhadap kesehatannya.

Kejadian diare dapat dihindarkan jika seorang ibu memiliki pengetahuan dan sikap yang baik dalam menangani diare. Pengetahuan dan sikap tersebut didapat dengan bertanya pada petugas kesehatan, kader ataupun dari pengalaman sendiri menangani diare. Sebelumnya pengetahuan maupun pengalaman ibu akan dapat membantu dalam menyikapi dan memutuskan tindakan atau perilaku yang akan diambil saat balita terserang diare.

Tingkat pengetahuan dan sikap yang dimiliki ibu nantinya akan mencerminkan perilaku dalam penanganan penyakit diare pada balita. Berdasarkan uraian di atas peneliti tertarik untuk mengetahui apakah ada hubungan tingkat pengetahuan dan sikap ibu balita dengan kejadian diare di Puskesmas Busungbiu II Kabupaten Buleleng.

\section{METODE}

Penelitian ini merupakan penelitian observasional dengan pendekatan cross sectional yang bertujuan untuk memberikan gambaran hubungan tingkat pengetahuan dan sikap ibu balita dengan kejadian diare di Puskesmas Busungbiu II Kabupaten Buleleng. Peneliti memperoleh data dari sampel melalui wawancara dan observasi kepada responden dengan menggunakan kuesioner dan lembar observasi, serta melakukan analisis data. Penelitian ini menggunakan sepuluh butir pertanyaan mengenai tingkat pengetahuan ibu tentang penanganan penyakit diare, sepuluh butir pertanyaan mengenai sikap ibu tentang penanganan penyakit diare dan dua pertanyaan tentang ada dan tidak ada keluhan diare pada balita.

Penelitian ini dilakukan di wilayah kerja Puskesmas Busungbiu II Kabupaten Buleleng tepatnya pada ibu yang memiliki balita yang beresiko terkena penyakit diare dengan mewawancarai dan mengamati keadaan sanitasi lingkungan rumah ibu yang memiliki balita. Jenis penelitian yang digunakan adalah analitik observasional dengan metode pendekatan crossectional dan uji statistik menggunakan uji analisis chi-square. 
Uji ini memiliki tujuan untuk mengetahui hubungan tingkat pengetahuan dan sikap ibu dengan penyakit diare pada balita di wilayah kerja Puskesmas Busungbiu II Kabupaten Buleleng. Tempat penelitian dilaksanakan di wilayah kerja Puskesmas Busungbiu II yang berlokasi di Desa Sepang Kecamatan Busungbiu Kabupaen Buleleng dan waktu penelitian dilaksanakan pada bulan Januari sampai dengan bulan Mei 2020. Jumlah responden sebanyak 40 orang dan pengambilan sampel dengan menggunakan teknik purposive sampling. Untuk menganalisis data yang didapat dimasukkan ke dalam uji statistik menggunakan uji Chi Square $\left(\mathrm{X}^{2}\right)$. Pengujian dilakukan dengan menggunakan perangkat komputer dengan menggunakan SPSS for windows. Uji analisis ini dilakukan untuk mengidentifikasi hubungan antara variabel bebas terhadap variabel terikat. Interpretasi hasil dilakukan jika Ho ditolak dan Ha diterima bila didapatkan nilai $\mathrm{p}<0,05$. Artinya ada hubungan tingkat pengetahuan dan sikap ibu balita dengan kejadian diare. Sedangkan Ho diterima dan Ha ditolak bila didapatkan nilai $\mathrm{p}>0,05$ (2). Artinya tidak hubungan tingkat pengetahuan dan sikap ibu balita dengan kejadian diare.

HASIL

Berdasarkan hasil penelitian diperoleh hasil yaitu sebagian besar responden memiliki pendidikan sampai sekolah menengah (SMP dan SMA) yaitu sebanyak 50\%. Sedangkan berdasarkan usia responden terbanyak berusia antara 21 sampai dengan 35 tahun yaitu sebanyak 62,5\%. Responden dengan tingkat pengetahuan ibu balita kategori baik dalam penanganan penyakit diare didapatkan sebanyak 70\%. Responden dengan sikap ibu balita kategori positif (baik) dalam penanganan penyakit diare didapatkan sebanyak $62,5 \%$

Analisis data yang digunakan adalah Crosstabs atau uji silang antara variabel tingkat pengetahuan dan sikap dengan variabel kejadian diare. Hasil uji crosstabs adalah sebagai berikut:

1. Hubungan tingkat pengetahuan dengan kejadian diare pada balita

Berdasarkan analisis data hasil penelitian yang dilakukan dengan menggunakan uji crosstabs mengenai hubungan tingkat pengetahuan responden dengan kejadian diare pada balita di Puskesmas Busungbiu II secara terperinci dapat di lihat di tabel 1. 
Tabel 1

Hasil Uji Crosstabs Hubungan Pengetahuan Responden Dengan Kejadian Diare Pada Balita di Puskesmas Busungbiu II Kabupaten Buleleng

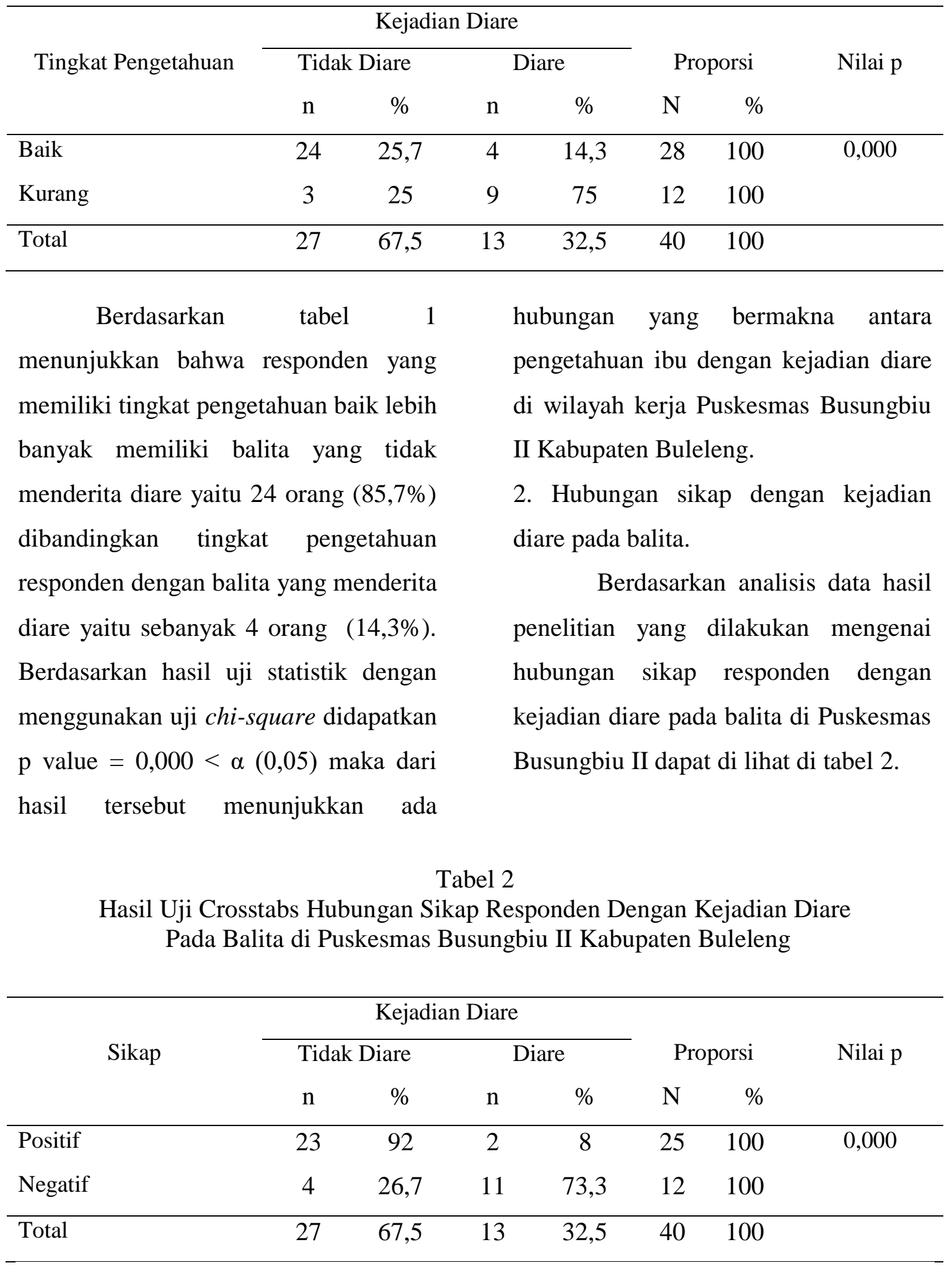


Pada tabel 2 didapatkan hasil bahwa responden dengan sikap positif yang memiliki balita tidak diare sebanyak 23 orang (92\%) sedangkan responden dengan sikap positif memiliki balita yang diare sebanyak 2 orang $(8 \%)$. Berdasarkan hasil analisis statistik dengan mempergunakan uji

\section{PEMBAHASAN}

1. Hubungan tingkat pengetahuan dengan kejadian diare pada balita

Berdasarkan tabel 1
menunjukkan bahwa responden yang memiliki tingkat pengetahuan baik lebih banyak memiliki balita yang tidak menderita diare yaitu 24 orang $(85,7 \%)$ dibandingkan dengan tingkat pengetahuan responden dengan balita yang menderita diare yaitu sebanyak 4 orang $(14,3 \%)$. Berdasarkan hasil uji statistik Chi - Square didapatkan p value $=0,000<\alpha(0,05)$ maka dari hasil perhitungan tersebut menunjukkan bahwa ada hubungan yang bermakna antara tingkat pengetahuan ibu balita dengan kejadian diare di Puskesmas Busungbiu II Kabupaten Buleleng. Artinya semakin baik tingkat pengetahuan ibu tentang penanganan diare, maka semakin rendah kejadian diare pada balita di Puskesmas Busungbiu II Kabupaten Buleleng.
Chi-Square diperoleh nilai signifikansi dengan $p$ value $=0,000<\alpha(0,05)$. Dari hasil tersebut menujukkan bahwa ada hubungan yang bermakna antara sikap ibu balita dengan kejadian diare di Puskesmas Busungbiu II Kabupaten Buleleng.

Hal ini didukung oleh sebuah penelitian menyatakan, bahwa terdapat hubungan antara pengetahuan (sig 0,039) dengan penyakit diare pada balita (3). Serta sejalan dengan penelitian yang dilakukan oleh Sukut dkk. (2015), bahwa terdapat hubungan antara pengetahuan (sig 0,004) dengan kejadian diare (4). Menurut penelitian yang telah dilakukan pada analisis bivariat menunjukkan bahwa ada hubungan antara tingkat pengetahuan ibu tentang penanganan diare dengan kejadian diare pada balita dimana pvalue $<\alpha(0,042 \leq 0,05)(5)$

Penelitian yang dilakukan oleh Khasanah dan Sari (2016) menyebutkan bahwa pengetahuan yang dimiliki oleh ibu di RW 2 sudah berada pada kategori cukup, akan tetapi masih ada 57,1\% yang memiliki pengetahuan yang kurang (6). Masih terdapatnya ibu balita yang memiliki pengetahuan kurang merupakan tuntutan dan peranserta dari petugas kesehatan untuk memberikan 
penyuluhan kesehatan tentang diare kepada ibu balita. Informasi yang diberikan yaitu tentang cara mencapai hidup sehat, cara memelihara kesehatan, cara menghindari penyakit yang akan meningkatkan pengetahuan ibu. Tingkat pengetahuan yang kurang menyebabkan ibu tidak mengerti cara penanganan diare pada anak. Hal ini disebabkaan karena mereka cenderung malas untuk melakukan sesuatu hal seperti mencari informasi atau mengikuti penyuluhan kesehatan yang diberikan oleh petugas kesehatan. Hasil penelitian kurang terhadap kejadian diare pada anak ini disebabkaan karena responden hanya sebatas tahu dan belum sampai memahami, mengaplikasikan, menganalisa, mensintesis, dan mengevaluasi terhadap suatu materi yang berkaitan dengan kejaadian diare.

Hal ini disebabkan karena $45 \%$ responden memiliki pendidikan sekolah dasar.

Menurut Erfandi (2009) salah penyebab yang dapat berpengaruh terhadap pengetahuan seseorang adalah pendidikan. Pendidikan akan mempengaruhi proses berfikir dan belajar, sehingga akan lebih mudah untuk menerima informasi. Apabila informasi kesehatan yang diterima semakin banyak maka akan semakin banyak pula pengetahuan yang didapat. Namun tidak selamanya pendidikan rendah membuat pengetahuan kurang (7) . Pendidikan non formal juga dapat memberikan pengetahuan, sehingga pengetahuan pengetahuan itu tidak hanya didapatkan dari pendidikan formal saja. Peneliti lain menegaskan bahwa faktor risiko yang ikut berperan pada kejadian diare salah satunya adalah karena kurangnya pengetahuan ibu tentang hal-hal yang dapat menimbulkan kejadian diare (8).

2. Hubungan sikap dengan kejadian diare pada balita

Pada tabel 2 didapatkan hasil bahwa responden dengan sikap positif memiliki balita yang tidak diare sebanyak 23 (92\%), sedangkan responden dengan sikap negatif memiliki balita yang diare sebanyak 2 orang (8\%). Hasil analisis statistik dengan mempergunakan uji Chi Square diperoleh nilai signifikansi dengan $\mathrm{p}$ value $=0,000<\alpha(0,05)$. Dari hasil perhitungan tersebut menunjukkan bahwa ada hubungan yang bermakna antara sikap ibu balita dengan kejadian diare di Puskesmas Busungbiu II. Artinya semakin positif (baik) sikap ibu tentang penanganan diare, maka semakin rendah kejadian diare pada balita di Puskesmas Busungbiu II 
Kabupaten Buleleng. Hal ini sejalan dengan penelitian yang dilakukan oleh Haryanti dan Sunardi (2010) yang menyatakan bahwa terdapat hubungan yang bermakna antara sikap ibu dengan kejadian diare $(\mathrm{p}$ value $=0,017)(9)$.

Sikap ibu yang merasa ragu untuk membawa balitanya ke fasilitas pelayanan kesehatan (puskesmas) kemungkinan dikarenakan kurangnya tingkat pengetahuan ibu mengenai penanganan penyakit diare pada balita, sehingga sikap yang ditimbulkan akan menjadi negatif atau buruk. Penyakit diare harus ditangani dengan cepat dan tepat. Apabila hal tersebut tidak segera dilakukan, maka akan bisa mengancam keselamatan jiwa anak. Maka dengan membawa segera anak ke fasilitas pelayanan kesehatan terdekat anak akan mendapatkan pertolongan dan perawatan serta penanganan diare yang optimal. Sehingga proses penyembuhan anak berjalan dengan cepat dan baik.

Sikap seseorang meliputi adanya proses menerima dan rangsangan atau stimulus, menanggapi pertanyaan dengan cara memberi pendapat, menilai dengan positif objek yang diketahui dan bertanggung jawab atas resiko yang muncul. Sikap seseorang dipengaruhi beberapa faktor meliputi pendidikan, media masa kejiwaan, emosi pengalaman pribadi serta lembaga pendidikan, (10).

Menurut Notoatmodjo (2010) sikap adalah juga respon tertutup pada seseorang terhadap stimulus atau objek tertentu yang sudah melibatkan pendapat dan emosi yang bersangkutan (suka-tidak suka, setuju tidak setuju). Sikap adalah kumpulan gejala yang merespon stimulus atau objek, sehingga sikap itu melibatkan pikiran, perasaan, perhatian dan sebagainya (10)

Berdasarkan hasil penelitian ini diperoleh bahwa responden yang memiliki balita menderita diare mempunyai tingkat pengetahuan yang kurang dan memiliki sikap negatif (buruk) terkait penanganan penyakit diare. Responden tersebut menganggap bahwa penanganan dan pengobatan diare sepenuhnya merupakan tugas petugas kesehatan. Adanya pengetahuan yang kurang dan sikap negatif responden dalam penanganan penyakit diare, untuk itu disarankan kepada petugas kesehatan agar dapat lebih aktif dan kreatif memberikan edukasi kesehatan mengenai cara penanganan penyakit diare. Sehingga harapan ke depan ibu balita yang datang berobat ke puskesmas agar lebih mengetahui tentang kejadian diare pada anak, dengan cara mencari informasi tentang 
apa-apa saja yang harus dilakukan saat anak terkena diare.

\section{SIMPULAN DAN SARAN}

Berdasarkan hasil penelitian hubungan tingkat pengetahuan dan sikap ibu balita dengan kejadian diare di Puskesmas Busungbiu II Kabupaten Buleleng dapat disimpulkan bahwa : (1) Tingkat pengetahuan ibu balita dengan kategori baik didapatkan sebanyak 70\%. (2) Sikap ibu balita dengan kategori positif (baik) didapatkan sebanyak 62,5\%. (3) Ada hubungan antara pengetahuan ibu balita dengan kejadian diare, artinya semakin baik tingkat pengetahuan ibu tentang penanganan diare, maka semakin rendah kejadian diare pada balita di Puskesmas Busungbiu II Kabupaten Buleleng. (4) Ada hubungan antara sikap ibu balita dengan kejadian diare, artinya semakin positif sikap ibu tentang penanganan diare, maka semakin rendah kejadian diare pada balita di Puskesmas Busungbiu II Kabupaten Buleleng. Sedangkan sarannya (1) Kepada ibu balita yang datang berobat ke puskesmas agar lebih mengetahui tentang kejadian diare pada anak, dengan cara mencari informasi tentang apa-apa saja yang harus dilakukan saat anak terkena diare. (2)
Kepada petugas kesehatan agar dapat lebih aktif dan kreatif memberikan edukasi kesehatan mengenai cara penanganan penyakit diare.

\section{DAFTAR PUSTAKA}

1. Hidayat AA. Pengantar Ilmu Keperawatan Anak. Jakarta:

Salemba Medika; 2006.

2. Sugiyono P. Statistik Untuk Penelitian. Bandung: Alfabeta; 2013

3. Sriwahyuni M. Hubungan Faktor Lingkungan dan Perilaku Ibu dengan Penyakit Diare Pada Balita di Surabaya. J Promkes Univ Airlangga. 2014;

4. Sukut S. Faktor Kejadian Diare Pada Balita Dengan Pendekatan teori Nola J. Pender di IGD RSUD Ruteng. J Ners Univ

Airlangga [Internet]. 2015;

Available from:

http//journal.unair.ac.id.

5. Yessi A. Hubungan Tingkat

Pengetahuan Ibu Tentang

Penanganan Diare Dengan

Kejadian Diare Pada Balita di

Kelurahan Korong Gadang

Kecamatan Kuranji Kota Padang.

J Kesehat Andalas [Internet].

2020;9. Available from:

Jurnal.fk.unand.ac.id/index.php/j 
ka/article/view/720/576

6. Khasanah U. Hubungan Tingkat

Pengetahuan Ibu Tentang Diare

Dengan Perilaku Pencegahan

Diare Pada Balita. J Kesehat

[Internet]. 2016; Available from:

https://media.neliti.com.

7. Erfandi. Pengetahuan dan faktor-

faktor yang mempengaruhi.

2009; Available from:

Forbetterhealth.wordpress.com\%

$0 \mathrm{~A}$
8. Ngastiyah. Perawatan Pada Anak

Sakit. Edisi II. Jakarta: EGC; 2005.

9. Haryanti T. Hubungan

Pengetahuan dan Sikap Ibu

Dengan Kejadian Diare Pada

Anak Balita di kerja Puskesmas

Polokarto Kabupaten Sukoharjo.

J Public Heal. 2010;19-37.

10. Notoatmodjo S. Promosi

Kesehatan Teori dan Aplikasi.

Jakarta: Rineka Cipta; 2010. 